\title{
How to Circumscribe Individualist Explanations
}

\section{A Reply to Elder-Vass}

Zahle, Julie

Published in:

Philosophy of the Social Sciences

DOI:

$10.1177 / 0048393114530857$

Publication date:

2014

Document version

Early version, also known as pre-print

Citation for published version (APA):

Zahle, J. (2014). How to Circumscribe Individualist Explanations: A Reply to Elder-Vass. Philosophy of the Social Sciences, 44(6), 810-816. https://doi.org/10.1177/0048393114530857 


\title{
How to Circumscribe Individualist Explanations: A reply to Elder-Vass
}

\author{
Julie Zahle \\ Section of Philosophy, Department of Media, Cognition and Communication, University of Copenhagen Denmark. \\ Email: jzahle@hum.ku.dk \\ Final draft - Forthcoming in Philosophy of the Social Sciences
}

\begin{abstract}
In "Redescription, Reduction, and Emergence: A response to Tobias Hansson Wahlberg," Elder-Vass takes the opportunity to reply to my criticism of his theory in "Holism, Emergence, and the Crucial Distinction." In this response, I show how methodological individualists may respond to his argument against their position and I argue that Elder-Vass fails to provide reasons as to why his particular distinction between individualist and holist explanations should be adopted.
\end{abstract}

\section{Keywords}

methodological individualism, methodological holism, ontological individualism, explanation, causal powers

Methodological individualists and holists differentiate between individualist explanations, i.e. explanations in terms of individuals, and holist explanations, i.e. explanations in terms of social entities such as states, schools, and the like. In his excellent book, The Causal Powers of Social Structures (2010), Dave Elder-Vass draws this distinction such that individualist explanations are not allowed to contain descriptions of, and presuppose, any relations between individuals. ${ }^{1}$ He has in mind here the sort of relations that must obtain between individuals, at a given moment in time, in order for them to form a social entity/whole. In a forthcoming paper, I point out that since the 1950s at least, most methodological individualists have relied on a broad notion of individualist explanations that allows these relations to be described and presupposed (Zahle forthcoming). This being the case, what are Elder-Vass' reasons to adopt a restrictive conception of individualist explanations? ${ }^{2}$ I present these reasons and argue that they are not good ones (ibid.). In "Redescription, Reduction, and Emergence: A response to Tobias Hansson Wahlberg" (2013), Elder-Vass takes the opportunity to address my criticism. I would like to thank Elder-Vass for his reply. In the following, I present his response in some detail. Then I move on to show why I think that it must be found wanting.

Elder-Vass proposes that broad methodological individualists, i.e. those who subscribe to a broad specification of individualist explanations, tend to presuppose or justify their stance by appeal to the thesis of ontological individualism (ibid.: 4). As Elder-Vass defines it, this is the view that social entities are not real and lack causal powers. Though he does not spell it out, Elder-Vass seems to assume that broad methodological individualists reason somewhat along the following lines: Because social entities lack causal

\footnotetext{
${ }^{1}$ In the following, I am only concerned with what Elder-Vass says about explanations in the sense of causal explanations. Thus, I do not discuss his alternative notion of reductive explanations.

2 In "Elder-Vass on the Causal Power of Social Structures," Hansson Wahlberg raises a similar criticism to the effect that Elder-Vass' definition of ontological individualism is very restrictive (2013:5-6).
} 
powers, it makes no sense to offer holist explanations which state how social entities, in virtue of their causal powers, brought about specific events. ${ }^{3}$ Individuals differ from social entities by being real and having causal powers. Accordingly, social scientists should confine themselves to offering broad individualist explanations that state how individuals, in virtue of their causal powers, brought about specific events. Be that as it may, Elder-Vass states that the only way broad methodological individualists defend the thesis of ontological individualism is by pointing out that it is always possible "to offer explanations of their [i.e. social entities'] purported causal contributions to social events purely in terms of the causal influence of individuals and the ways in which they are organized and related" (ibid.). In other words, explanations in terms of social entities may always be substituted by broadly specified explanations in terms of individuals. For this reason, Elder-Vass continues, broad methodological individualists insist that social entities should neither be regarded as real nor be ascribed any causal powers.

This last move forms the basis for Elder-Vass' attack: It is equally possibly, he notes, to explain how individuals' actions were brought about, not by them considered as wholes, but instead by their parts as suitably interrelated. That is, broadly specified explanations in terms of individuals may likewise be substituted by explanations in terms of individuals' parts and their interrelations. ${ }^{4}$ Consequently, Elder-Vass asks, why not say that individuals, too, lack causal powers? ${ }^{5}$ And, by implication, it may be added, why not hold that not only holist but also broad individualist explanations should be dispensed with? In view of this objection, Elder-Vass concludes that "if individualists do wish to make use of them [viz. broad individualist explanations], they need to justify why they can" (ibid.): Methodological individualists are not entitled to use explanations that describe and presuppose relations between individuals until they have refuted his objection against their position.

I think there are two problems with Elder-Vass' reply to my criticism. The first has to do with his argument against broad methodological individualism. There are various ways in which broad methodological individualists may react to it. In his rejoinder to Elder-Vass, Hansson Wahlberg points to one possible response namely to show that, different from social entities, individuals have extra causal powers (Hansson Wahlberg 2014:8). Yet he does not work out, and defend, this idea such that broad methodological individualists may rebut Elder-Vass' objection by appeal to it. I doubt that this task may be successfully carried out so I make no attempt to do so here. Broad methodological individualists are much better off pursuing another - very simple - strategy. It may be introduced by noting that Elder-Vass' objection applies to broad methodological individualists only insofar as they subscribe to: a) the thesis of ontological individualism and $b$ ) the view that because holist explanations may always be replaced by broad individualist explanations, social entities fall short of having causal powers. This means that broad methodological individualists who do not endorse a) and b) are not touched by Elder-Vass' argument. Accordingly, broad methodological individualists who already defend their stance while not endorsing a) and b) may simply respond to Elder-Vass' argument by pointing out that it fails to apply to them. And those broad methodological individualists who do reason in the manner outlined by Elder-Vass may just retract their espousal of a) and b). My impression is that when it comes to the more recent debate, most broad methodological individualists fall within the first category, that is, independently of Elder-Vass' argument,

\footnotetext{
${ }^{3}$ To be precise, Elder-Vass maintains that causal explanations only specify how one aspect of an event was partially brought about (Elder-Vass 2010:178). For the sake of simplicity, I use the more crude formulation of his view.

${ }^{4}$ Elder-Vass points out that an explanation in terms of individuals' parts may in turn be replaced by an explanation in terms of the parts of individuals' parts plus their interrelations, and so on. To keep things simple, I ignore this point in the following.

${ }^{5}$ For this line of reasoning, see also Elder-Vass (2010:55).
} 
they do not subscribe to a) and b). But in any event, the upshot is the same. Broad methodological individualists may present - or may come up with - this sort of response to Elder-Vass and hence they may dismiss his contention that they need to justify the use of broad individualist explanations: There is no basis for holding that they are not entitled to use broad individualist explanations.

It is clear that those broad methodological individualists who give up a) and b) to avoid ElderVass' objection must find some other way in which to spell out and defend their position. One option is that they follow Elder-Vass in holding both that social entities are real and have causal powers, and that holist explanations may be replaced by broad individualist explanations that may, in turn, be substituted by explanations in terms of individuals' parts and their relations. Like many other methodological individualists, they may then argue, on the one hand, that broad individualist explanations should always be favored over holist ones because they are more fine-grained and, on the other hand, that it falls outside the domain of the social sciences to advance explanations in terms of individuals' parts and their interrelations. Thus, social scientists should offer broad individualist explanations only. ${ }^{6}$ Obviously, ElderVass may also bring charges against these - and other - arguments in support of broad methodological individualism. But note that it is only once he has actually done so that he is in a position to claim that the methodological individualists who offer these arguments must justify their use of broad individualist explanations. Until then, their employment should be regarded as acceptable.

The second and more serious problem with Elder-Vass' reply is that it does not really answer my criticism. Elder-Vass maintains that methodological individualists are not allowed to make use of broad individualist explanations until they have dealt with his objection. The implication is that as long as the objection has not been repudiated, Elder-Vass is within his rights not to circumscribe individualist explanations broadly: In view of his objection, he is entitled to resist the suggestion to specify individualist explanations broadly. To make this point is not the same as showing why it is a good idea, in the first place, to draw the distinction between individualist and holist explanations such that individualist explanations are narrowly specified. To see the difference, note that Elder-Vass' reason to prefer a narrow specification of individualist explanations is unlikely to be that if they are broadly specified, the thesis of methodological individualism faces his objection. Because why should he, as an opponent of methodological individualism, care about choosing a distinction between individualist and holist explanations such that methodological individualists do not run into serious trouble? And indeed he doesn't. Elder-Vass thinks that another objection, the argument from emergence, may be mounted against the thesis of methodological individualism when individualist explanations are circumscribed in the manner he favors, that is, narrowly (Elder-Vass 2010:23ff \& 54ff). These considerations form the basis for my claim that Elder-Vass does not really answer my criticism. In my paper, I argue that he does not provide good reasons, in his (2010), as to why his preferred distinction between individualist and holist explanations should be espoused (Zahle forthcoming). That is, he fails to offer convincing reasons as to why it is a good idea, in the first place, to draw the distinction in his favorite manner. Elder-Vass' response to my query does not take care of this problem since, as I have just shown, it does not present any positive reasons in support of drawing the distinction such that individualist explanations are narrowly circumscribed.

\footnotetext{
${ }^{6}$ The idea that individualist explanations are always preferable to holist ones because they are more fine-grained is widespread among methodological individualists. It is explicitly espoused by, e.g., Elster (1985:5). For a particularly interesting - and critical - discussion of this view, see Jackson and Pettit (1992). With respect to the claim that it lies outside the domain of the social sciences to offer explanations in terms of individuals' parts and their relations, see, e.g., Watkins (1973[1952]:156).
} 
The challenge I present to Elder-Vass' account raises the more general question of what would actually constitute good reasons in support of a particular distinction between individualist and holist explanations. In my forthcoming paper, I observe that a distinction should serve a useful purpose. Otherwise why draw it, let alone insist on it? Moreover, I propose that a good reason in support of a given distinction between individualist and holist explanations is one that shows, in an acceptable manner, that the distinction, drawn in the same way in all contexts, is useful from the perspective of offering social scientific explanations (Zahle forthcoming). In his (2010), Elder-Vass makes it clear that his distinction is designed such as to map onto, or line up with, an ontological distinction that he regards as prior to, and more basic than, his distinction between individualist and holist explanations. However, it is not obvious why it is useful, from the perspective of offering social scientific explanations, to draw the distinction such that it maps onto his particular ontological distinction. It is exactly this issue, I think, that needs to be addressed.

In my view, all participants in the methodological individualism-holism debate, broad methodological individualists included, should be required to provide good reasons, in the sense defined above, in favor of their particular distinctions between individualist and holist explanations. This will make it possible finally to make some headway in the protracted disagreement as to how individualist and holist explanations should be circumscribed. Depending on the outcome, it may then be determined to what extent, and in what form, to carry on the methodological individualism-holism debate. ${ }^{7}$

\footnotetext{
${ }^{7}$ I would like to thank Finn Collin, Tobias Hansson Wahlberg, Tuukka Kaidesoja, Jakob Lindgaard, and Petri Ylikoski for helpful discussions and suggestions.
} 


\section{References}

Elder-Vass, Dave. 2010. The Causal Power of Social Structures. Cambridge, UK: Cambridge University Press.

Elder-Vass, Dave. 2013. "Redescription, Reduction, and Emergence: A Response to Tobias Hansson Wahlberg," Philosophy of the Social Sciences. Advance online publication, doi: 10.1177/004839311351538.

Elster, Jon. 1985. Making Sense of Marx. Cambridge: Cambridge University Press.

Hansson Wahlberg, Tobias. 2013. "Elder-Vass on the Causal Power of Social Structures," Philosophy of the Social Sciences. Advance online publication. doi: 0048393113500213.

Hansson Wahlberg, Tobias. 2014. "Causally Redundant Social Objects: Rejoinder to Elder-Vass." Philosophy of the Social Sciences. Advance online publication. doi: 0048393114521364.

Jackson, Frank \& Pettit Philip. 1992. "In Defense of Explanatory Ecumenism" in Economics and Philosophy, 8, pp. 1-21.

Watkins, J.W.N. 1973[1952]. "Ideal Types and Historical Explanation" in Modes of Individualism \& Collectivism, edited by J. O'Neill. London: Heinemann, pp. 143-165.

Zahle, Julie. Forthcoming. "Holism, Emergence, and the Crucial Distinction." In Rethinking the IndividualismHolism Debate, edited by J. Zahle and F. Collin. Dordrecht, the Netherlands: Springer. 